\title{
Effects of Oral Administration of Camel Milk and Urine on Gut Microbiota: Biochemical and Microbiological Profiling in Rats
}

\author{
Samah 0. Noor, Manal S. Alenini \\ Biology Department, Faculty of Science, King Abdulaziz University, Jeddah, KSA \\ Email: magdammali@hotmail.com
}

How to cite this paper: Noor, S.O. and Alenini, M.S. (2018) Effects of Oral Administration of Camel Milk and Urine on Gut Microbiota: Biochemical and Microbiological Profiling in Rats. American Journal of Molecular Biology, 8, 1-12.

https://doi.org/10.4236/ajmb.2018.81001

Received: November 29, 2016

Accepted: November 19, 2017

Published: November 22, 2017

Copyright (c) 2018 by authors and Scientific Research Publishing Inc. This work is licensed under the Creative Commons Attribution International License (CC BY 4.0).

http://creativecommons.org/licenses/by/4.0/

\begin{abstract}
Human intestinal tract contained a diverse number of microbial communities which performed a significant role in human health. The presence of gut microbiota was affected mainly by diet. Camel milk is the source of nutrition and provides all the essential nutrients for growth. It has great significance in the treatment of liver, spleen, and anemic infections. Camel urine has also many medical advantages. In this study we examined the effect of camel milk and urine and a mixture of both (milk + urine) on the growth of Gut microbiota using an in vivo animal model. Fresh fecal samples were collected before and after administration of the tested materials. After that, the microbial analysis was conducted via culturing, denaturing gradient gel electrophoresis and metabolic analysis via high-performance liquid chromatography (HPLC). The result indicated that the numbers of bacterial groups were increased after the first dose. Coliform group have significant increase when given a mix of milk and urine compared to control group with $\mathrm{P}<0.05$. Bifidobacterium group have significant increase in their number in the Milk and Mix groups compared to control group with $\mathrm{P}<0.05$. The concentration of Short-chain fatty acids in fecal samples was increased in Milk and Mix groups compared to control group. In conclusion, drinking camal milk, urine or a mix of both increased the growth of Gut microbiota.
\end{abstract}

\section{Keywords}

Camal Milk, Urine, Gut Microbioa, HPLC, DGGE

\section{Introduction}

The human gastrointestinal tract (GIT) extends from the oral cavity to the rec- 
tum and is colonized by a large number of microorganisms. There are more than $10^{14}$ organisms in the human colon alone with at least 400 species, approximately 10 times more than the sheer number of somatic cells [1] [2]. Microbiota in the colon and rectum is much more diverse and larger than the population of upper parts of GIT. The main objectives of the microbiota in the intestine are metabolic (Trophic function), barrier effect (protective) and enhancement of the immune system [3]. The colon is the main site for fermentation due to slower transit rate and rich nutritional environment. The main products of gut bacterial fermentation in the colon are the short-chain fatty acids (SCFAs). SCFAs stimulate the cell proliferation and differentiation of intestinal enterocytes [3] [4] [5]. The techniques for the study of microbial communities in the intestine are diverse, generally two methods are applied: Culture-based and Culture-Independent techniques including Polymerase Chain Reaction (PCR), Denaturing Gradient Gel Electrophoresis (DGGE), Fluorescence in situ hybridization, Cloning and Sequencing [6] [7] [8].

For many decades, the natural products were applied in the fields of medicine, pharmacy, biology and have very essential role in health care and prevention of diseases [9]. Animals have been a source of some interesting compounds that can be used as drugs. One of these is Camels that have a medical importance through their milk and urine. Medical uses of camel milk and urine which were known in previous generations were proven by modern scientific research. The lactoferrin found in camel milk (ten times greater than in cow milk), has anti-microbial and anit-viral activities such as lysozyme and immunoglobulins [10] [11]. Also it is effective against pathogens including Staphylococcus aureus and E. coli [12]. Camel's urine has medicinal properties through its use as a disinfectant agent for wiping wounds and sores. It also helps to block hair damage and baldness, and can be applied as a remedy for dandruff [13]. Moreover, camel's urine may be helpful to treat blood clots and dropsy (deficiency of albumin and potassium). The Camel's urine also provides a panacea for abdominal pains, liver infection such as hepatitis and digestive diseases [14]. Prof. Faten Khorshid and his coworkers proved effectiveness of camel urine and the active substance in the treatment of many types of cancer, such as leukemia, lung cancer and colon cancer [15] [16] [17] [18] [19]. In this study, the effect of camel milk and a mix of both milk and urine on the growth of Gut microbiota and their metabolic activity in vivo animal model were determined. The effect of both treatments on the colonic rat tissue was also determined.

\section{Material and Methods}

\subsection{Experimental Animals}

Fifteen albino wistar male rats of the same age with a body weight of $200-250 \mathrm{~g}$ were collected from the Animal House Unite of King Fahd Medical Research Center, King Abdulaziz University, Jeddah, Saudi Arabia. All the studies were conducted in accordance with the ethics and regulation of local governing au- 
thorities. Animals were housed in respective plastic cages and divided into three groups: Milk, Mix and control groups. Each group has 5 animals. All experiments were run in the same controlled environment $\left(21^{\circ} \mathrm{C} \pm 2^{\circ} \mathrm{C}, 65 \%\right.$ relative humidity and 12: 12 hour light/dark cycle).

\subsection{Collection of Camel Products and Treatment Methods}

Camel milk and urine were collected from camels that graze in south Jeddah, Saudi Arabia from adult female in the morning in sterilize bottles and kept at $4^{\circ} \mathrm{C}$ until used. A daily dose of camel milk $(1.8 \mathrm{ml} / 200 \mathrm{~g})$ was given to the first rat group and a dose of $2.4 \mathrm{ml} / 200 \mathrm{~g}$ of mix (camel milk + urine, $\mathrm{v} / \mathrm{v}$ ) was given to the rat second group through oral gavages for one week. The third group is a control that drank water instead of milk or urine.

\subsection{Collection of Fecal Sample}

Fresh fecal samples were collected at different time points in sterile plastic containers. Containers were kept under anaerobic conditions in anaerobic Jar. Each week, three fecal samples/week were collected from each rat for two weeks, labeled, and then stored at $-20^{\circ} \mathrm{C}$ until used.

\subsection{Plate Counting}

The bacterial groups that were tested, the selective media and culture conditions that were used were shown in Table 1. Fecal samples were dissolved in water $(10 \% \mathrm{w} / \mathrm{v})$ and serial dilutions for each fecal sample were prepared. The plats which contained the selective media were inoculated with $100 \mu \mathrm{l}$ of each dilution. Then, all plates were incubated at $37^{\circ} \mathrm{C}$ or $45^{\circ} \mathrm{C}$ under proper conditions.

\subsection{Determination of Amount of Short Chain Fatty Acid}

Short chain fatty acids (SCFAs) like Acetic, Propionic, Isobutyric and Lactic were investigated in fecal samples of the three tested animal groups. Water extract from fecal samples were prepared [20] and $10 \mu \mathrm{l}$ of the extract was injected directly into HPLC System (Shimadzu LC-20AS Liquid Chromatography) using a C18 column (Shimadzu, $250 \times 4.6 \mathrm{~mm}$ ) at $60^{\circ} \mathrm{C}$. Diluent of Sulfuric acid and $2 \%$ methanol was used as a mobile phase at a flow rate of $1 \mathrm{ml} / \mathrm{min}$. The SCFAs were detected using a UV detector set at wavelength of $210 \mathrm{~nm}$.

Table 1. Selective Media and incubation condition that were used to cultivation gut bacteria.

\begin{tabular}{ccccc}
\hline The selective media & Bacteria & $\begin{array}{c}\text { Incubation } \\
\text { Temperature }\end{array}$ & $\begin{array}{c}\text { Incubation } \\
\text { Period }\end{array}$ & $\begin{array}{c}\text { Incubation } \\
\text { Condition }\end{array}$ \\
\hline MRS agar & Lactobacilli & $37^{\circ} \mathrm{C}$ & 7 days & Anaerobic \\
Beerns agar & Bifidobacterium & $37^{\circ} \mathrm{C}$ & 7 days & Anaerobic \\
Azide blood agar & Streptococci & $45^{\circ} \mathrm{C}$ & 3 days & Aerobic \\
MacConkey agar & Coliform & $37^{\circ} \mathrm{C}$ & 1 day & Aerobic \\
\hline
\end{tabular}




\subsection{DNA Extraction and PCR}

Bacterial DNA was extracted from $200 \mathrm{mg}$ of frozen fecal samples $\left(-20^{\circ} \mathrm{C}\right)$ using QIAamp DNA stool Mini kit, according to the manufacturer's instructions. The DNA concentration was measured using Nanodrop spectrophotometer and quality was evaluated using gel electrophoresis. The DNA that isolated from collected fecal samples was used as a template in PCR amplification. The V3 region of $16 \mathrm{~S}$ rRNA was targeted to amplify the total DNA bacterial community using universal primer. The forward primer (341GC-F) (5'CGC CCG GGG CGC GCC CCG GGC GGG GCG GGG GCA CGG GGG G CCT ACG GGA GGC AGC AG 3') GC-clamp is in boldface) and the reverse primer (534R)(5-ATT ACC GCG GCT GCT GG-3) were used [21]. The PCR products were purified with Ethanol/EDTA/Sodium Acetate precipitation method following Applide Biosystems protocol (2002). The DNA concentration and purity were measured at 260 and $280 \mathrm{~nm}$ using Nanodrop spectrophotometer.

\subsection{DGGE}

In this study, the DNA that was extracted from fecal samples from all experimental groups of rats at different time points were analyzed using DGGE which was performed using Bio-Rad Protein 11 system, essentially as described by [22]. DGGE with 6\% polyacrylamide gel containing 30\% - 50\% linear denaturant gradient (100\% denaturant corresponds to $7 \mathrm{M}$ urea and $40 \%$ deionised formamide) was used. Sample (190 ng) of each purified PCR product was loaded onto the gel. DGGE was performed at $60^{\circ} \mathrm{C}$ and $200 \mathrm{~V}$ for $1 \mathrm{hr}$ in $1 \times$ TAE buffer. Gels were stained with ethidium bromide $(20 \mu \mathrm{l}$ in $200 \mathrm{ml}$ of $1 \times$ TAE buffer for 20 min) and then visualised under UV light and photographed using gel documentation. All the samples were analyzed on the similar DGGE run to avoid the probable influence of variations in electrophoretic conditions between different runs. DGGE images were analysed by TotalLab Quant software.

\subsection{Histological Studies}

To investigate the histological changes in the rat colons, sigmoid colon sections, stained using Hematoxylin and Eosin and examined using light microscope [23].

\subsection{Statistical Analysis}

Statistical analysis was applied using the statistical Package software for Social Science (SPSS for windows, version 16). The significance of the difference between groups was determined using the One-Way ANOVA. The difference was regarded significant when $\mathrm{P}<0.05$ and non-significant when $\mathrm{P}>0.05$.

\section{Results}

\subsection{Plate Count Data}

After administracion of camel milk and mix (camel milk and urine) to rats for a week, seven rat fecal samples were collected during 2 weeks. Each fecal sample 
was cultivated on the selective media to investigate the different groups of bacteria in the rat feces. The data revealed that using camel milk or a mix of both milk and urine increased all types of tested bacteria compared to control (zero time). Results of the enumeration of cultivable bacteria are presented in Figure 1 and Figure 2.

The results also indicated that the Coliform group has the highest growth in the Mix fed group with $1.6 \times 10^{9} \mathrm{cfu} / \mathrm{ml}$, after the first week. This increase was significant compared to control group with $\mathrm{P}<0.05$. The growth of the same group of bacteria was also increased in Milk fed group $\left(2.2 \times 10^{5} \mathrm{cfu} / \mathrm{ml}\right)$ compared to control. The enumeration of Streptococci bacteria showed the highest growth in the Mix fed group with $1.3 \times 10^{5} \mathrm{cfu} / \mathrm{ml}$, while $1.7 \times 10^{4} \mathrm{cfu} / \mathrm{ml}$ in the Milk feed group. However this increase was not significant in comparison to control group $(\mathrm{P}>0.05)$. The results also showed that the Lactobacilli group was increased in numbers to $2.4 \times 10^{6} \mathrm{cfu} / \mathrm{ml}$ and $2.3 \times 10^{6} \mathrm{cfu} / \mathrm{ml}$ in Milk and Mix groups, respectively. Bifidobacterium group showed similar increase in their growth with $1.42 \times 10^{6}$ and $1.46 \times 10^{6} \mathrm{cfu} / \mathrm{ml}$ in the Milk feed group and Mix fed group, respectively. This increase was significant compared to the control group with $\mathrm{P}<0.05$. In the milk fed group, the growth of Coliform and Streptococci

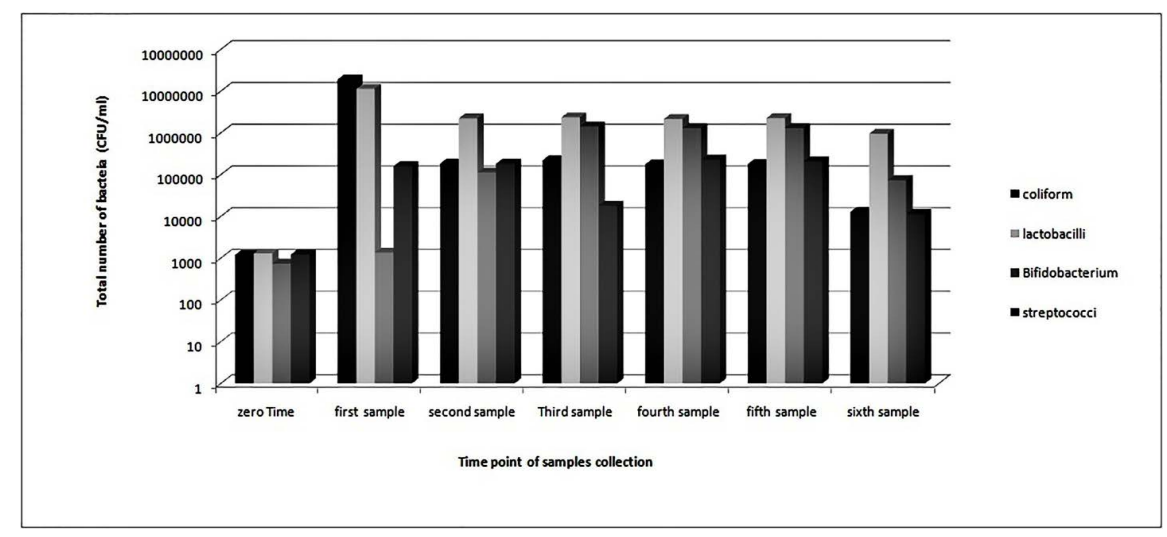

Figure 1. Enumeration of total number of bacteria $(\mathrm{CFU} / \mathrm{ml})$ from fecal samples of rats after oral administration of camel milk for two weeks.

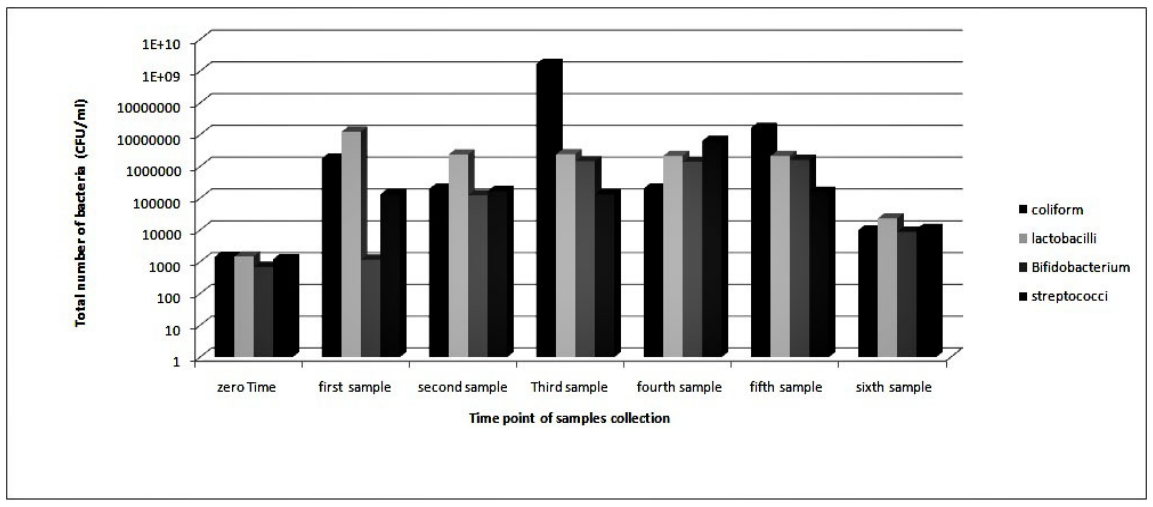

Figure 2. Enumeration of total number of bacteria $(\mathrm{CFU} / \mathrm{ml})$ from rat fecal samples after oral administration of a mixture of milk + urine for two weeks. 
were decreased after stopping the milk doses while the decrease was not clear in case of Lactobacilli and Bifidobacterium. In the mix fed group, the growth of all bacterial groups decreased after the last dose.

\subsection{Metabolic Analysis}

In the HPLC chromatograms that were obtained from fecal water analysis, different concentrations of SCFAs were obtained. The result of the average concentrations of the SCFAs is presented in Figure 3. The concentration of lactate increased in the milk feed group by $85 \%$, while its concentration decreased in the mix feed group by $45 \%$ after the first dose. After administration of milk and urine, the concentration of acetate in the mix feed group was decreased by $59 \%$, while its concentration in the milk feed group was increased by $63 \%$. The concentration of Isobutyrate in the milk and mix groups was increased by $57 \%$ and $46 \%$, respectively. However concentration of propionate acid was decreased after starting dosing in the mix group by about $39 \%$. In the milk group its concentration was increased by about $77 \%$.

\subsection{DGGE Analysis}

Figure 4 showed the DGGE profile where each line represent a sample from

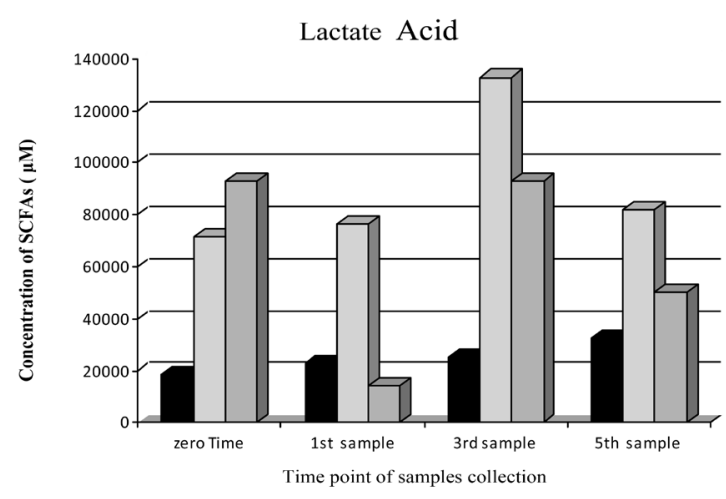

(a)

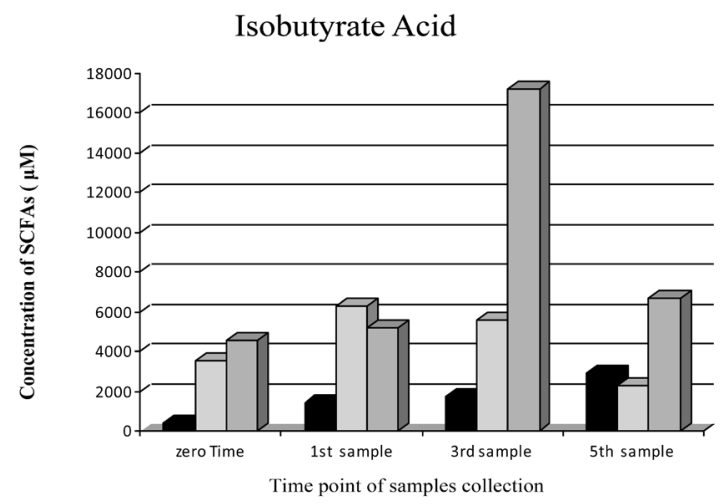

(c)

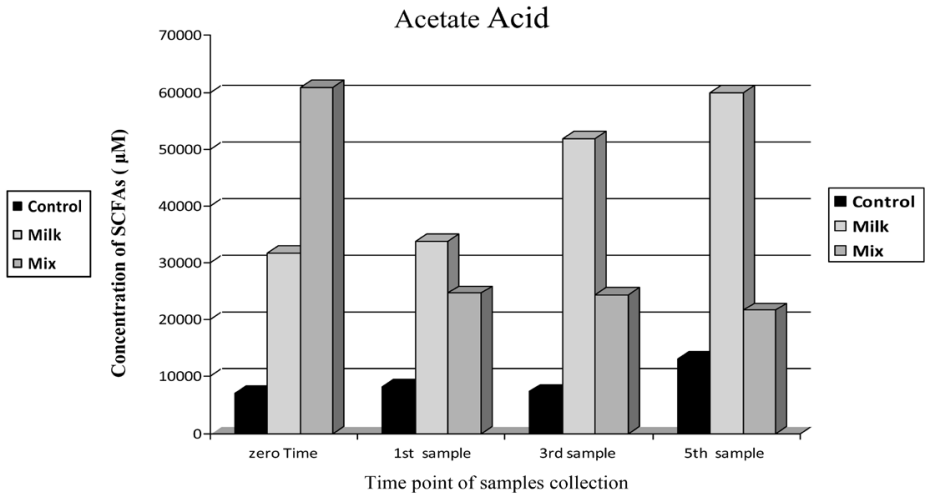

(b)

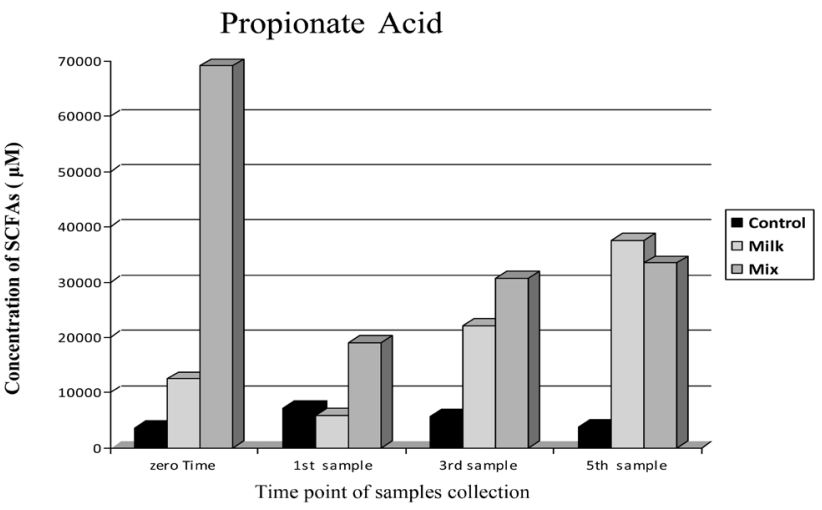

(d)

Figure 3. The average of concentration $(\mu \mathrm{M})$ of SCFAs that analysis by HPLC for the Control, milk and mix groups before and after dosing. (a) Lactate acid; (b) Acetate acid; (c) Isobutyrate acid; (d) Propionate acid. 


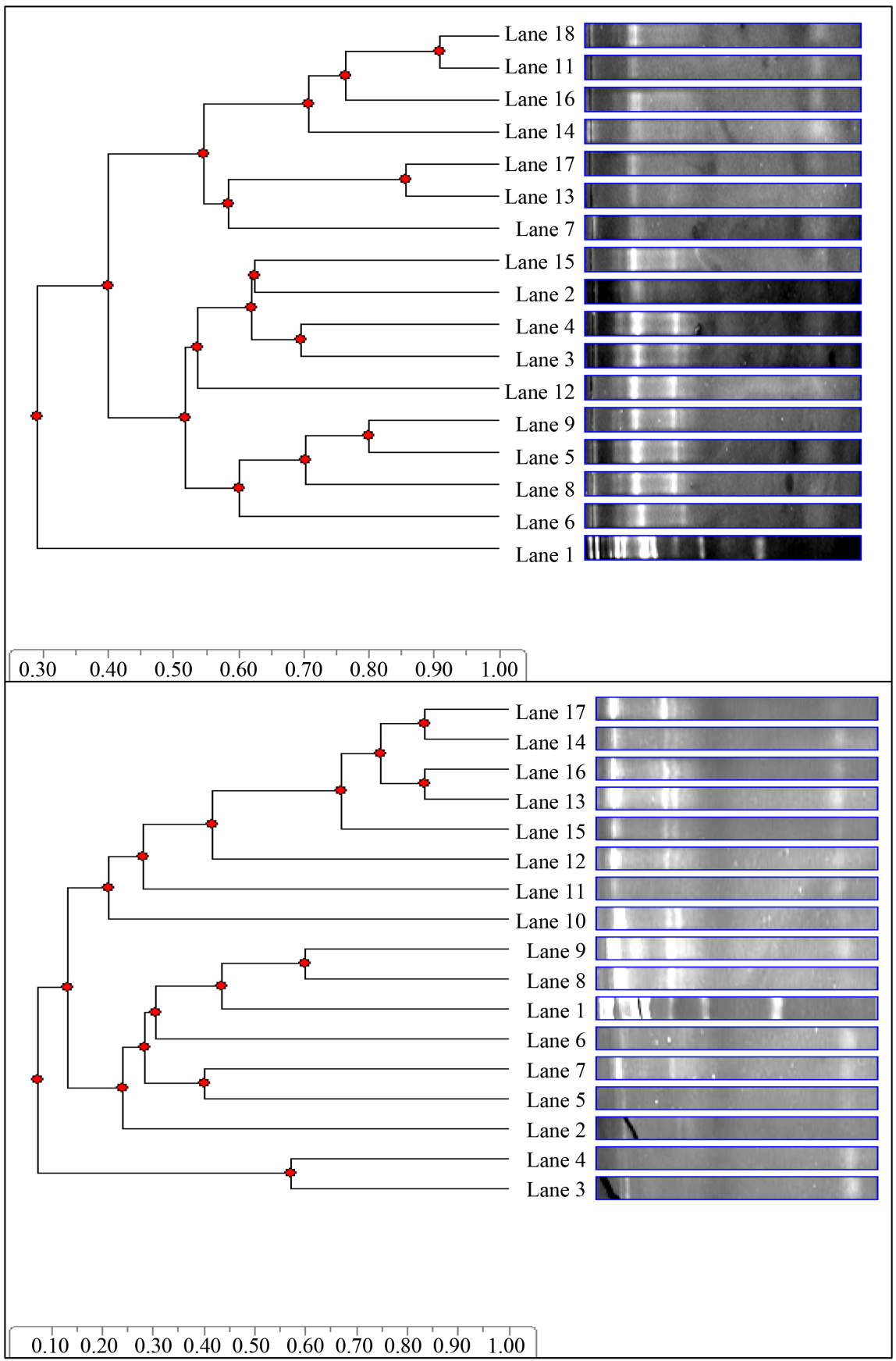

Figure 4. Dendrogram showing similarity between bacteria in milk group (a) and Mix group (b).

individual rat. The bands in each line represent different bacterial group. The intensity of the band may provide an assessment of the fraction of the target bacterial group in the sample. The microbial diversity was evaluated by the count of bands existence in the DGGE patterns.

The milk feed group showed a stable number of bands through the dosing period. The mean of number of bands was $8 \pm 1$ bands. When comparing the intensity of bands in this group, most bands had an increase in their intensity after 
administrated of milk. The bands with $\mathrm{R}_{\mathrm{f}}=0.009,0.026$ and 0.849 were increased by about 2 - 3 folds and these increases were significant $(P=0.001)$. One band with $\mathrm{R}_{\mathrm{f}}=0.196$ has imperceptibly increase. The increase in the intensity of those bands indicates an increase in the numbers of these bacterial groups.

Interestingly, in the group that was feed on mixture of milk and urine, the bacterial diversity remained the same after the first three doses while after the fourth dose there was a substantial increase in microbial diversity (number of bands $9 \pm 1$ ) with $\mathrm{P}=0.003$. Additionally, although there were no increase at the first three time points, the intensity of one of the bands $\left(R_{f}=0.101\right)$ has ten folds increase after the third feeding point. This increase was translated into a rise in number of this particular group of bacteria. On the other hand there was a significant decrease in the intensity of another band $\left(\mathrm{R}_{\mathrm{f}}=0.331\right)$ which indicates the loss of numbers of this bacterial group (Table 2).

\subsection{Histological Studies}

Microscopic examination of the colon tissue showed that there are no changes in the structure of the colon tissues (colonic mucosa, submucosa and muscular), but there was an increase in the intensity of the mucus layer in the treaded groups compared to control group, as indicated in Figure 5.

\section{Discussion}

Microbiota in gastrointestinal tract plays a key role in human health [24]. Therefore, we must preserve the microbial community balanced and healthy. Camel's milk has many healing factors and all the essential nutrients for growth [25]. The current work, investigated the impact of these camel products on gut microbiota and their metabolic activity in the digestive system in rats.

The enumeration results of fecal bacteria which investigated before and after camel products administrations indicated that the numbers of tested bacterial groups were increased after the first doses. This might be due to the presence of Lactic acid bacteria (LAB) in camel milk, while some researchers reported that lactic acid bacteria (LAB) exist in numerous food products, also are part of natural microbial community in gastrointestinal tract [26]. The results of [19]

Table 2. The rate of flow $\left(\mathrm{R}_{\mathrm{f}}\right)$ value and intensity of bands detected from DGGE gels.

\begin{tabular}{cccc}
\hline \multirow{2}{*}{ Rat group } & R & \multicolumn{2}{c}{ Intensity of bands } \\
\cline { 3 - 4 } Camel Milk & 0.009 & $\begin{array}{c}\text { Before dosing } \\
\text { (zero time) }\end{array}$ & $\begin{array}{c}\text { After dosing } \\
\text { (after 2 weeks }\end{array}$ \\
\hline & 0.026 & 4970.17 & 8392.78 \\
& 0.849 & 4204.19 & 12153.93 \\
Mix (camel milk + urine) & 0.196 & 22322.36 & 83157.14 \\
& 0.101 & 14008.48 & 142938.88 \\
& 0.331 & 32068.27 & 11281.34 \\
\hline
\end{tabular}




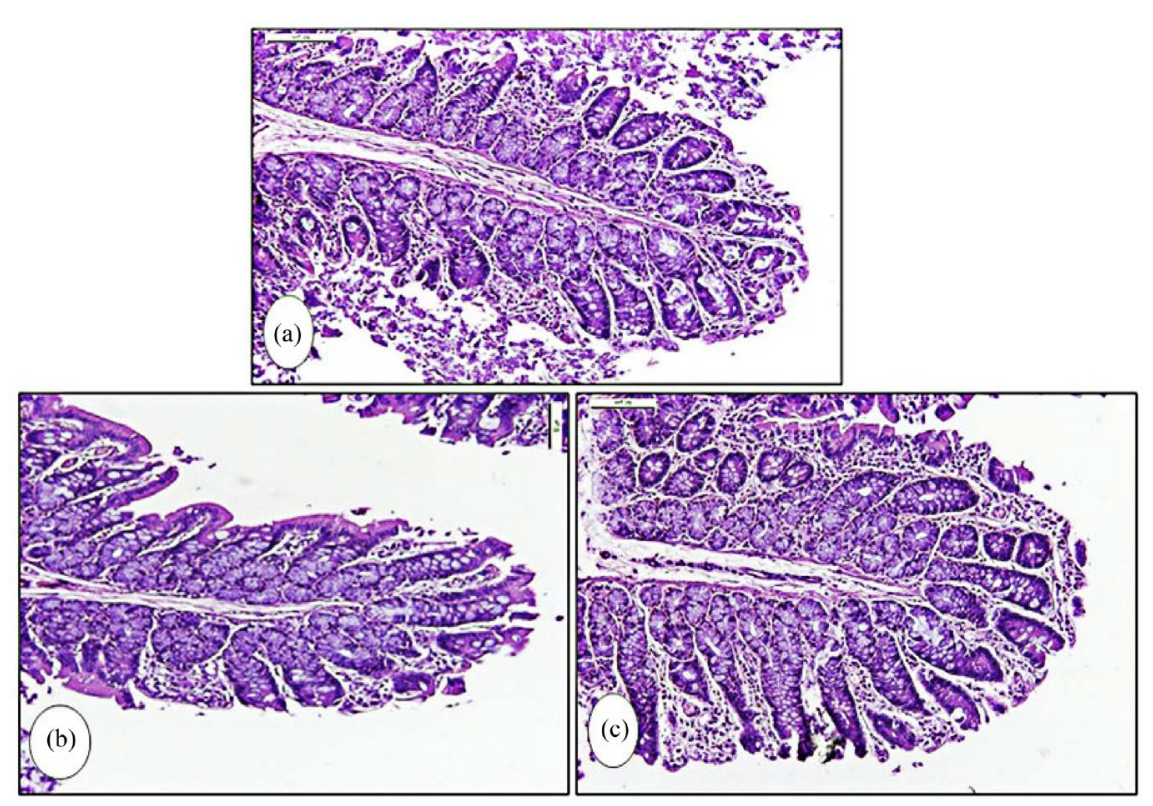

Figure 5. The effect of oral administration of Milk (b) and Mix (c) on colonic tissue of rats, showed normal structure of colonic inucosn. subinucosa and muscular and no differences are seen compared with control jeroup (a), except the mucous layer has increased in its thickness $(\mathrm{H} \& \mathrm{E} \times 20)$.

stated that the camel milk represent a source of biological material in dairy products, due to the existence of lactic acid bacteria which are beneficial bacteria. Moreover, more free amino acids and peptides are found in camel milk than in bovine milk which is digested by microorganisms, and therefore, camel milk presents a higher metabolic activity when used in a culture preparation [27]. A study of [28] investigated the antimicrobial activity of Camel's urine; some normal bacteria were isolated from camel urine including E. coli, and lactic acid bacteria (LAB). In this study, DGGE method was selected for study gut microbiota, because the culture-dependent technique showed only culturable bacteria while molecular method monitor the entire DNA in the sample.

Most previous studies have monitored the shift in DGGE patterns by correlating the presence and absence of bands, or switch in the intensity of a single band on the same gel [29]. In this study, DGGE method was used as quantitative method and the intensity of the most bands that were detected in the gel for the study groups was increased, which indicates an increase in the numbers of the bacterial groups. On the other hand, there was a decrease in the intensity of other bands which indicates a drop in the number of some bacterial group.

The main products of gut bacterial fermentation in the colon are the shortchain fatty acids (SCFAs) which can be detected in fecal samples. However, the actual proportion of these products depends on many factors such as diet [30]. Variation in the gut microbiota composition is likely to affect metabolic function. The SCFAs investigated in this study were increased in Milk and Mix fed groups compared to control group. This might be due to the fundamental nutrients for growth and development that found in camel milk, including proteins 
carbohydrates, fatty acids, minerals and growth factors [31].

In this study, sigmoid colon was selected to examine the histological changes in the colon using light microscope, where its main objective is to store feces until enters the rectum and expelled through the anus, and it is the site of wide range of complications. Ulcerative colitis and Crohn's (inflammatory bowel diseases) may occur here. Also, the diverticulitis is more common in the sigmoid than any other part of the bowel, as well as cancers that prefer the sigmoid colon. The mucus layer functions as a dynamic protective barrier and interacts with the commensal microbiota to keep a steady maintenance and balance. This homeostasis between mucus and the microbiota is damaged in a variety of intestinal disorders, including IBD, where as in these patients, mucosal inflammation was shown to be associated with a reduction in the diversity of the microbiota. More specifically, a loss of anaerobic bacteria such as Bacteroides, Eubacterium, and Lactobacillus species was reported [32] [33]. Our examined histological sections of sigmoid colon indicated no observable significant effect on tissues structure, except the mucus thickness which was increased in the treated rats by camel products compared to control group $(\mathrm{P}<0.05)$.

\section{Conclusion}

The results obtained in this study suggested that the presence of free amino acids and Lactic acid bacteria in Camel milk may play an important role as a natural source to improve the microbial community in the gastrointestinal tract. These results may encourage the consumption of camel milk as a source of nutrition providing the essential nutrients for growth and development of our metabolic activity.

\section{Acknowledgements}

The authors acknowledge with thanks Prof. Faten khorshid who provided us with the pure PMF fraction and helped with the dosing calculation, the study design and project supervision.

\section{References}

[1] Abu Shanab, Y. (1992) Camels in the Arab World. Dar Al Wasem, Damascus.

[2] Abu-Taraboush, H., Al-Dagal, M. and Al-Royli, M. (1998) Growth, Viability and Proteolytic Activity of Bifidobacteria in Whole Camel Milk. Journal Dairy Science, 81, 345-361. https://doi.org/10.3168/jds.S0022-0302(98)75584-5

[3] Al-Ani, F. (2003) Encyclopedia Camels. Dar Al-Shorok for Publishing \& Distribution, Amman. (In Arabic)

[4] Al-Hashem, F. (2009) Camel's Milk Protects against Aluminum Chloride-Induced Toxicity in the Liver and Kidney of White Albino Rats. American Journal of Biochemistry and Biotechnology, 5, 98-108. https://doi.org/10.3844/ajbbsp.2009.98.108

[5] Macpherson, A.J. and Therese, U. (2004) Induction of Protective IgA by Intestinal Dendritic Cells Carrying Commensal Bacteria. Science, 303, 1662-1665. 
https://doi.org/10.1126/science.1091334

[6] Al-Zahrani, S. and Al-Harbi, A. (2011) Antimicrobial Activity of Camel's Urine on Methicillin-Resistant Staphylococcus aureus Isolated from Clinical Specimens. King Abdulaziz University Journal, Science, 23, 251-268.

https://doi.org/10.4197/sci.23-1.16

[7] De Baere, S., Eeckhaut, V., Steppe, M., De Maesschalck, C., De Backer, P., Van Immerseel, F. and Croubels, S. (2013) Development of a HPLC-UV Method for the Quantitative Determination of Four Short-Chain Fatty Acids and Lactic Acid Produced by Intestinal Bacteria during In Vitro Fermentation. Journal of Pharmaceutical and Biomedical Analysis, 80, 107-115.

https://doi.org/10.1016/j.jpba.2013.02.032

[8] De Vuyst, L. and Leroy, F. (2007) Bacteriocins from Lactic Acid Bacteria: Production, Purification, and Food Applications. Journal of Molecular Microbiology and Biotechnology, 13, 194-199. https://doi.org/10.1159/000104752

[9] El-Hatmi, H., Girardet, J., Gaillard, J., Yahyaoui, M. and Attia, H. (2007) Characterisation of Whey Proteins of Camel (Camelus dromedarius) Milk and Colostrum. Small Ruminant Research, 7, 267-271. https://doi.org/10.1016/j.smallrumres.2006.04.001

[10] Faure, M., Mettraux, C., Moennoz, D., Godin, J., Vuichoud, J., Florence Rochat, F., Breuille, D., Obled, C. and Corthésy-Theulaz, I. (2006) Specific Amino Acids Increase Mucin Synthesis and Microbiota in Dextran Sulfate Sodium-Treated Rats. American Society for Nutrition, 136, 1558-1564.

[11] Fromin, N., Hamelin, J., Tarnawski, S., Roesti, D., Jourdain-Miserez, K., Forestier, N., Teyssier-Cuvelle, S., Gillet, F., Aragno, M. and Rossi. P. (2002) Statistical Analysis of Denaturing Gel Electrophoresis (DGE) Fingerprinting Patterns. Environmental Microbiology, 4, 634-643. https://doi.org/10.1046/j.1462-2920.2002.00358.x

[12] Guarner, F. and Malagelada, J. (2003) Gut Flora in Health and Disease. Lancet, 361, 512-519. https://doi.org/10.1016/S0140-6736(03)12489-0

[13] Hooper, L.V., Wong, M.H., Thelin, A., Hansson, L., Falk, P.C. and Gordon, J.I. (2001) Molecular Analysis of Commensal Host-Microbial Relations Hips in the Intestine. Science, 291, 881-884. https://doi.org/10.1126/science.291.5505.881

[14] Khedid, K., Faid, M., Mokhtari, A., Soulaymani, A. and Zinedine, A. (2009) Characterization of Lactic Acid Bacteria Isolated from the One Humped Camel Milk Produced in Morocco. Microbiological Research, 164, 81-91. https://doi.org/10.1016/j.micres.2006.10.008

[15] Khorshid, F. (2008) Preclinical Evaluation of PM 701 in Experimental Animals. International Journal of Pharmacology, 4, 443-451.

https://doi.org/10.3923/ijp.2008.443.451

[16] Khorshid, F., Moshref, S. and Heffnym, N. (2005) An Ideal Selective Anticancer Agent In Vitro, I-Tissue Culture Study of Human Lung Cancer Cells A549. JKAU-Medical Sciences, 12, 3-18. https://doi.org/10.4197/Med.12-1.1

[17] Khorshid, F. (2009) Potential Anticancer Natural Product against Human Lung Cancer Cells. Trends in Medical Research, 4, 9-15.

[18] Koehn, F. and Carter, G. (2005) The Evolving Role of Natural Products in Drug Discovery. Nature Reviews Drug Discovery, 4, 206-220. https://doi.org/10.1038/nrd1657

[19] Macfarlane, G. and Macfarlane, S. (1997) Human Colonic Microbiota: Ecology, Physiology and Metabolic Potential of Intestinal Bacteria. Scandinavian Journal of Gastroenterology, 222, 3-9. https://doi.org/10.1080/00365521.1997.11720708 
[20] McCartney, A. (2002) Application of Molecular Biological Methods for Studying Probiotics and the Gut Flora. British Journal of Nutrition, 88, S29-S37. https://doi.org/10.1079/BJN2002627

[21] Moshref, S., Khorshid, F. and Jamal, Y. (2006) The Effect of PM 701 on Mice Leukemic Cells: I-Tissue Culture Study of L1210 (In Vitro) II-In Vivo Study on Mice. JKAU-Medical Sciences, 13, 3-19. https://doi.org/10.4197/Med.13-1.1

[22] Muyzer, G., De Waal, E.C. and Uitterlinden, A.G. (1993) Profiling of Complex Microbial Populations by Denaturing Gradient Gel Electrophoresis Analysis of Polymerase Chain Reaction-Amplified Genes Coding for 16S rRNA. Applied and Environmental Microbiology, 59, 695-700.

[23] Muyzer, G., Brinkhoff, T., Nubel, U., Santegoeds, C., Schafer, H. and Wawer, C. (2004) Denaturing Gradient Gel Electrophoresis (DGGE) in Microbial Ecology. Molecular Microbial Ecology Manual, 1 \& 2, 743-769.

[24] Noor, S., Ridgway, K., Scovell, L., Kemsley, E., Lund, E., Jamieson. C., Johnson. I. and Narbad, A. (2010) Ulcerative Colitis and Irritable Bowel Patients Exhibit Distinct Abnormalities of the Gut Microbiota. BMC Gastroenterology, 12, 134. https://doi.org/10.1186/1471-230X-10-134

[25] Ruqayyah, L. (2002) Cancer Treatment of Camel Milk and Urine. http://www.khayma.com/roqia

[26] Sekirov, I., Russell, S., Antunes, L. and Finlay, B. (2010) Gut Microbiota in Health and Disease. Physiological Reviews, 90, 859-904.

[27] Sliewska, K., Klewicka, E. and Motyl, I. (2008) The Microflora of the Human Being. In: Technical Microbiology. Microorganisms and Environment of Their Occurrence, Oxford University Press, Oxford, 240-248.

[28] Stolarczyk, A., Libudzisz, Z., and Socha, J. (2008) The Role of Probiotics and Prebiotics in the Prevention and Treatment of Metabolic Syndrome in Children and Adolescents Angry. Standards Medical, 2, 175-171.

[29] Yassin, M., Soliman, M., Mostafa, S. and Ali, H. (2015) Antimicrobial Effects of Camel Milk against Some Bacterial Pathogens. Journal of Food and Nutrition Research, 3, 162-168. https://doi.org/10.12691/jfnr-3-3-6

[30] den Besten, G., van Eunenm K., Groen, A., Venema, K., Reijngoud, D. and Bakker, B. (2013) The Role of Short-Chain Fatty Acids in the Interplay between Diet, Gut Microbiota, and Host Energy Metabolism. The Journal of Lipid Research, 54, 2325-2340. https://doi.org/10.1194/jlr.R036012

[31] Ballard, O. and Morrow, A. (2013) Human Milk Composition: Nutrients and Bioactive Factors. Pediatric Clinics of North America, 60, 49-74. https://doi.org/10.1016/j.pcl.2012.10.002

[32] Ott, S.J., Musfeldt, M. and Wenderoth, D.F. (2004) Reduction in Diversity of the Colonic Mucosa Associated Bacterial Microflora in Patients with Active Inflammatory Bowel Disease. Gut, 5, 3685-3693. https://doi.org/10.1136/gut.2003.025403

[33] Kühbacher, T., Ott, S.J., Helwig, U., Mimura, T., Rizzello, F., Kleessen, B., Gionchetti, P., Blaut, M., Campieri, M., Fölsch, U.R., Kamm, M.A. and Schreiber, S. (2006) Bacterial and Fungal Microbiota in Relation to Probiotic Therapy (VSL\#3) in Pouchitis. Gut, 55, 833-841. https://doi.org/10.1136/gut.2005.078303 